\title{
Humic substances as a washing agent for Cd-contaminated soils
}

\author{
Fande Meng ${ }^{\mathrm{a}, \mathrm{b}}$, Guodong Yuan ${ }^{\mathrm{a},{ }^{* *}}$, Jing Wei ${ }^{\mathrm{a}}$, Dongxue Bi ${ }^{\mathrm{a}, \mathrm{b}}$, Yong Sik Ok ${ }^{\mathrm{c}}$, \\ Hailong Wang d, e, f, *
}

\footnotetext{
${ }^{a}$ Key Laboratory of Coastal Environmental Processes and Ecological Remediation, Yantai Institute of Coastal Zone Research (YIC), Chinese Academy of Sciences (CAS), Shandong Provincial Key Laboratory of Coastal Environmental Processes, YICCAS, Yantai, Shandong 264003, China

${ }^{\mathrm{b}}$ University of Chinese Academy of Sciences, Beijing 100049, China

c School of Natural Resources and Environmental Science \& Korea Biochar Research Center, Kangwon National University, Chuncheon 24341, South Korea

d School of Environment and Chemical Engineering, Foshan University, Foshan, Guangdong 528000, China

e Key Laboratory of Soil Contamination Bioremediation of Zhejiang Province, Zhejiang A\&F University, Lin'an, Zhejiang 311300, China

${ }^{\mathrm{f}}$ Guangdong Dazhong Agriculture Science Co. Ltd., Hongmei Town, Dongguan City, Guangdong 523169, China
}

\section{H I G H L I G H T S}

- Leonardite is an excellent source of humic substances.

- Humic substances as a washing agent effectively removed Cd from contaminated soils.

- $\mathrm{Cd}$ in effluent was easily removed by $\mathrm{Ca}(\mathrm{OH})_{2}$.

\section{A R T I C L E I N F O}

\section{Article history:}

Received 14 February 2017

Received in revised form

9 April 2017

Accepted 24 April 2017

Available online 25 April 2017

\section{Keywords:}

Cadmium

Calcium hydroxide

Leonardite

Soil remediation

Soil washing

\begin{abstract}
A B S T R A C T
Cost-effective and eco-friendly washing agents are in demand for Cd contaminated soils. Here, we used leonardite-derived humic substances to wash different types of $\mathrm{Cd}$-contaminated soils, namely, a silty loam (Soil 1), a silty clay loam (Soil 2), and a sandy loam (Soil 3). Washing conditions were investigated for their effects on $\mathrm{Cd}$ removal efficiency. Cadmium removal was enhanced by a high humic substance concentration, long washing time, near neutral $\mathrm{pH}$, and large solution/soil ratio. Based on the tradeoff between efficiency and cost, an optimum working condition was established as follows: humic substance concentration (3150 mg C/L), solution $\mathrm{pH}(6.0)$, washing time $(2 \mathrm{~h})$ and a washing solution/soil ratio (5). A single washing removed $0.55 \mathrm{mg} \mathrm{Cd} / \mathrm{kg}$ from Soil 1 ( $1.33 \mathrm{mg} \mathrm{Cd} / \mathrm{kg}), 2.32 \mathrm{mg} \mathrm{Cd} / \mathrm{kg}$ from Soil 2 (6.57 mg $\mathrm{Cd} / \mathrm{kg})$, and $1.97 \mathrm{mg} \mathrm{Cd} / \mathrm{kg}$ from Soil $3(2.63 \mathrm{mg} \mathrm{Cd} / \mathrm{kg})$. Cd in effluents was effectively treated by adding a small dose of calcium hydroxide, reducing its concentration below the discharge limit of $0.1 \mathrm{mg} / \mathrm{L}$ in China. Being cost-effective and safe, humic substances have a great potential to replace common washing agents for the remediation of Cd-contaminated soils. Besides being environmentally benign, humic substances can improve soil physical, chemical, and biological properties.
\end{abstract}

(c) 2017 Elsevier Ltd. All rights reserved.

\section{Introduction}

Soil contamination by $\mathrm{Cd}$ is a common problem in many parts of the world, posing a threat to human health. In China, for example, $\mathrm{Cd}$ is the most commonly occurring metal contaminant in soils (The Ministry of Environmental Protection and the Ministry of Land and

\footnotetext{
* Corresponding author. School of Environment and Chemical Engineering, Foshan University, Foshan, Guangdong 528000, China.

** Corresponding author. Yantai Institute of Coastal Zone Research, China.

E-mail addresses: gdyuan@yic.ac.cn (G. Yuan), nzhailongwang@163.com (H. Wang).
}

Resources of the People's Republic of China, 2014). As Cd cannot be chemically or biologically degraded, immobilization or mobilization becomes the technology of choice for the remediation of soils that are contaminated with heavy metals (Bolan et al., 2014).

Immobilization may involve the addition to soil of solid adsorbents such as biochar (Yang et al., 2016; Lu et al., 2017; Wu et al., 2017), while mobilization is often achieved by washing soil with one or more of the following chemicals: metal chelating agents (e.g., EDTA), salts (e.g., $\mathrm{CaCl}_{2}, \mathrm{FeCl}_{3}$ ), strong acids (e.g., $\mathrm{HCl}$, $\mathrm{CH}_{3} \mathrm{COOH}$ ), or surfactants (e.g., 1-dodecylpyridinium chloride) (Mulligan et al., 2001; Conte et al., 2005; Zeng et al., 2005; Makino et al., 2007, 2008, 2016; Kulikowska et al., 2015a,b; Guo et al., 2016). 
Based on a desorption process, soil washing is one of the most effective remediation techniques as it removes heavy metals from contaminated soils (Dermont et al., 2008). Soil washing, however, has the potential of causing problems. For example, the washing agent EDTA is difficult to decompose (Tandy et al., 2004; Zeng et al., 2005), and hence is detrimental to soil microbial health (BucheliWitschel and Egli, 2001), soil porosity (Heil et al., 1999), and groundwater quality. $\mathrm{FeCl}_{3}$ and strong acids could acidify soil and adversely affect soil fertility and microbial activity (Rousk et al., 2009). Many washing surfactants are toxic to microbes, and their effluents could contaminate water bodies. Thus, there is an ongoing search for cost-effective and eco-friendly washing chemicals. In this regard, humic substances have the potential of becoming the washing chemicals of choice (Soleimani et al., 2010; Kulikowska et al., 2015b). Besides being environmentally benign, humic substances can improve soil physical, chemical, and biological properties.

Humic substances are operationally divided into three fractions based on their solubility in alkali or acid, namely, humic acid which is, alkali-soluble, fulvic acid which is alkali- and acid-soluble, and humin which is insoluble in both alkali and acid. Humic substances have traditionally been viewed as a mixture of high molecular weight ( $>10,000 \mathrm{Da}$ ), randomly coiled, negatively charged macromolecules. This concept, however, is being displaced by one in which humic substances consist of aggregates of biologically derived molecules of relatively low molecular weight (200-3000 Da) bound by weak dispersive forces and forming micelles in solution (Theng and Yuan, 2008; Theng, 2012). Organic matter in soil is now broadly viewed as a continuum spanning the full range from intact plant material to highly oxidized carbon in carboxylic acids (Lehmann and Kleber, 2015).

Of particular relevance to the present investigation is the abundant occurrence in humic substances of carboxyl and phenolic hydroxyl groups, resulting in a cation exchange capacity (CEC) of $600-890 \mathrm{cmol}(+) / \mathrm{kg}$ for humic acid and $1000-1230$ for fulvic acid (Tan, 2014) which is about 5-100 times higher than that of common clay minerals (Yuan et al., 2013). Humic substances can bind heavy metals by forming surface complexes with carboxyl and phenolic hydroxyl groups (Conte et al., 2005). Humic substances can be extracted from a variety of materials, such as leonardite and sewage sludge (Kulikowska et al., 2015a). Since leonardite may be likened as ancient biochar, the humic substances extracted from this source may be likened to a surface-activated biochar (Meng et al., 2016).

We have developed a humic substances-based technology to remove $\mathrm{Cd}$ from contaminated soils, involving the following steps: (1), extracting humic substances from leonardite; (2), using the humic substances as a washing agent; and (3), treating the resultant effluent (wastewater). To this end, we obtained water-soluble humic substances by treating leonardite with $\mathrm{KOH}$, conducted batch experiments to determine the effects of humic substance concentration, liquid-solid ratio, solution $\mathrm{pH}$, and washing time, on $\mathrm{Cd}$ removal efficiency, and then used calcium hydroxide to treat the washing effluent.

\section{Materials and methods}

\subsection{Soil sampling and analysis}

Samples of surface soil $(0-30 \mathrm{~cm})$ were collected from different regions in China (Table 1). Soil 1 and Soil 2 were taken from two contaminated farmlands near a nonferrous metal smelter in Hunan Province that has been in operation for many decades. Soil 3 was taken from an apple orchard in Yantai, Shandong Province, spiked with $\mathrm{Cd}\left(\mathrm{NO}_{3}\right)_{2}$ solution $(12 \mathrm{mg} \mathrm{Cd} / \mathrm{L})$ at a solid:liquid ratio of $5(\mathrm{~g} /$
Table 1

Basic properties of soil samples.

\begin{tabular}{lllll}
\hline & Unit & Soil 1 & Soil 2 & Soil 3 \\
\hline Sand content & $\%$ & 40.5 & 24.8 & 81.9 \\
Silt content & $\%$ & 50.1 & 56.3 & 15.2 \\
Clay content & $\%$ & 9.4 & 18.9 & 2.9 \\
Texture & - & Silty loam & Silty clay loam & Sandy loam \\
Organic carbon & $\%$ & 2.16 & 1.88 & 1.73 \\
pH $\left(\mathrm{H}_{2} \mathrm{O}\right)$ & - & 6.57 & 6.16 & 5.51 \\
Total $\mathrm{Cd}$ & $\mathrm{mg} / \mathrm{kg}$ & 1.33 & 6.57 & 2.63 \\
\hline
\end{tabular}

$\mathrm{ml}$ ), and aged at room temperature for two months. After airdrying, grinding to pass a 2-mm sieve, and thorough mixing, the soil samples were analyzed for the following properties: (1), particle size using a Mastersizer 2000 (Marlvern, UK); (2), organic carbon using an elemental analyzer (Vario macro cube, Elementar, Germany); (3), $\mathrm{pH}$ in distilled water (1:5 w/v ratio) using a $\mathrm{pH}$ meter (Mettler Toledo, Switzerland); and (4), pseudo-total Cd concentration by placing $1 \mathrm{~g}$ of soil (dried at $105^{\circ} \mathrm{C}$ ) into a polytetrafluoroethylene vessel, adding a $\mathrm{HCl}: \mathrm{HNO}_{3}$ mixture (Sinopharm, China) at 3:1 ratio $(\mathrm{v} / \mathrm{v})$, and heating in a microwave oven (one-stage program; $\mathrm{t}=160{ }^{\circ} \mathrm{C}$ ). After cooling, the extracts were filtered through $0.45 \mu \mathrm{m}$ membrane into $50 \mathrm{~mL}$ glass flasks, filled to the mark with ultra-pure water, and analyzed by inductively coupled plasma mass spectrometry (ICP-MS) (Elan DRC II, PerkinElmer, USA).

\subsection{Humic substances and their analysis}

The humic substances were obtained by extracting a leonardite from Shanxi Province with $0.1 \mathrm{M} \mathrm{KOH}$, acidifying the extract to $\mathrm{pH} 7$ with $\mathrm{HCl}$, and keeping the supernatant. By operational definition, the derived humic substances comprise a mixture of water-soluble humic acid and fulvic acid. The high solubility of the material is of fundamental importance for our purposes as conventional humic acid is practically insoluble in water, and hence is unsuitable for use as a washing agent, while the cost of producing conventional fulvic acid is uneconomical for this purpose.

The humic substances were analyzed for (1), elemental composition using the same elemental analyzer mentioned above; (2), content of carboxyl and phenolic groups by an International Humic Substances Society method (IHSS, 2016); (3), surface tension at pH 6 using a tensiometer (Fangrui, China); (4), critical micelle concentration (CMC) by plotting surface tension against humic substance concentration; and (5), total heavy metal concentration by weighing $0.1 \mathrm{~g}$ of dried $\left(105^{\circ} \mathrm{C}\right)$ humic substances into a polytetrafluoroethylene vessel, adding a $\mathrm{HClO}_{4}: \mathrm{HNO}_{3}: \mathrm{HF}$ mixture (Sinopharm, China) at a 3:1:1 ratio $(\mathrm{v} / \mathrm{v} / \mathrm{v})$, and heating in a microwave oven. The extracts were then filtered through $0.45 \mu \mathrm{m}$ membrane into 50 - $\mathrm{mL}$ glass flasks, filled to the mark with ultrapure water, and analyzed with the same ICP-MS mentioned above.

\subsection{Establishing optimum washing conditions}

The washing efficiency of the humic substances from leonardite was compared with that of a commercial fulvic acid (Shanghai Macklin Biochemical Co., Ltd.) with a chemical formula of $\mathrm{C}_{14} \mathrm{H}_{12} \mathrm{O}_{8}$, a molecular weight of $308.2 \mathrm{Da}$, a carboxyl content of $3.17 \mathrm{~mol}(+) /$ $\mathrm{kg} \mathrm{C}$, and a hydroxyl content of $3.04 \mathrm{~mol}(+) / \mathrm{kg} \mathrm{C}$.

The effect of washing conditions on Cd removal efficiency was assessed by batch experiments conducted in duplicate at room temperature. Polyethylene tubes containing soil samples and solutions of either humic substances or fulvic acid were placed on a shaker, oscillating at $120 \mathrm{rpm}$. The variables included humic 
substances or fulvic acid concentration $(0,157.5,315,630,945$, $1260,1575,1890,2520,3150,3780$, and $4725 \mathrm{mg} \mathrm{C} / \mathrm{L})$, solution/soil ratio $(3,5,7,9,10,12,15,20,30 \mathrm{v} / \mathrm{w})$, solution $\mathrm{pH}(3,4,5,6,7,8,9)$, and washing time $(0.5,1,2,4,6,8,12 \mathrm{~h})$. At the end of the washing cycle, the tubes were centrifuged at $3000 \mathrm{rpm}$ for $15 \mathrm{~min}$, the supernatants were filtered through a $0.45 \mu \mathrm{m}$ membrane, and the concentration of the various metals was determined by atomic absorption spectrometry (AAS, TAS-990, China). Organic carbon was measured using a TOC-VCPH Total Organic Carbon Analyzer (Shimadzu, Japan).

\subsection{Effluent treatment}

An effluent sample was collected from washing experiment for treatment to remove $\mathrm{Cd}$. A batch experiment (in duplicate at room temperature) was conducted to determine the effectiveness of calcium hydroxide for treating washing effluents. Briefly, $10 \mathrm{~mL}$ of effluent with a $\mathrm{pH}$ of 7.13 and a Cd concentration of $0.32 \mathrm{mg} / \mathrm{L}$ was placed in $15 \mathrm{~mL}$ polyethylene tubes, and $0.05,0.1,0.2,0.3,0.4 \mathrm{~g}$ $\mathrm{Ca}(\mathrm{OH})_{2}$ was added. After shaking at $120 \mathrm{rpm}$ for $2 \mathrm{~h}$ on an oscillating shaker, the tubes were centrifuged at $3000 \mathrm{rpm}$ for $15 \mathrm{~min}$. The supernatants were filtered through a $0.45 \mu \mathrm{m}$ membrane, and the concentration of Cd in the filtrate was determined by AAS (TAS990, China).

\subsection{Calculation and statistical analysis}

Cd adsorption by humic substances was estimated from the difference in Cd concentration before and after washing the soil with the washing agent. Software OriginPro 8.0 (OriginLab. USA) was used for data analysis.

\section{Result and discussion}

\subsection{Critical micelle concentration and total acidity of humic substances and fulvic acid}

Critical micelle concentration (CMC) of a surfactant is the threshold concentration at which micelles begin to form. Its magnitude has a determining influence on the suitability of a given surfactant for use as a washing agent in that the smaller the CMC the better the washing efficiency (Mulligan et al., 2001; Mao et al., 2015). Fig. 1 shows that CMC of the leonardite-derived humic substances ( $1890 \mathrm{mg} \mathrm{C} / \mathrm{L}$ at the corresponding surface tension of $54.6 \mathrm{mN} / \mathrm{m}$ ) is lower than that of fulvic acid (3150 $\mathrm{mg} \mathrm{C} / \mathrm{L}$ at $47.62 \mathrm{mN} / \mathrm{m}$ ). The humic substances would therefore be a better washing agent than the fulvic acid from Macklin. By comparison,
Kulikowska et al. (2015b) reported a CMC of $1101 \mathrm{mg}$ C/L at pH 7 for humic substances from compost, increasing to $1215 \mathrm{mg} \mathrm{C} / \mathrm{L}$ at $\mathrm{pH}$ 13.

In having a high concentration of carboxyl groups ( $6.70 \mathrm{~mol}(+) /$ $\mathrm{kg} \mathrm{C})$ and phenolic hydroxyl groups $(5.44 \mathrm{~mol}(+) / \mathrm{kg} \mathrm{C})$, the humic substances from leonardite would have a large propensity for adsorption of $\mathrm{Cd}$ and other metals by forming stable inner-sphere complexes with such groups (Tan, 2014). In order to desorb Cd from clay surfaces, the affinity of a washing agent for the metal contaminant should exceed that of soil clays.

\subsection{Humic substances or fulvic acid concentration and Cd removal efficiency}

As expected, the Cd removal efficiency of humic substances and fulvic acid increased with the concentration of the washing agent (Fig. 2). By forming complexes with humic substances (Yuan and Theng, 2011), soil clays would reduce the efficiency of washing agents in removing $\mathrm{Cd}$ from soil. For this reason, concentration higher than the CMC would be required for good washing effect. Furthermore, the higher the humic substance concentration, the more carboxyl and phenolic hydroxyl groups would be available for $\mathrm{Cd}$ complexation. For the same carbon concentration, humic substances could therefore remove more $\mathrm{Cd}$ from the contaminated soils as compared with fulvic acid.

Cd removal efficiency was markedly enhanced as the concentration of washing agent increased $(0-4725 \mathrm{mg} \mathrm{C} / \mathrm{L})$. This effect was evident with humic substances than fulvic acid, particularly when the concentration of the washing agent was below the CMC. The Cd removal efficiency is much higher for Soil 3 than for either Soil 1 or Soil 2, probably because Soil 3 was lighter in texture (contained less clay), and had a shorter aging time of spiked $\mathrm{Cd}$. We used a humic substance concentration of $3150 \mathrm{mg} \mathrm{C/L}$ (higher than its CMC) and adjust the liquid-solid ratio, $\mathrm{pH}$, and washing time to optimize $\mathrm{Cd}$ removal efficiency.

\subsection{Effect of liquid-solid ratio on Cd removal efficiency}

As expected, Cd removal efficiency increased with liquid-solid ratio until a plateau was approached (Fig. 3). At a liquid-solid ratio of $20, \mathrm{Cd}$ removal efficiency was $87.2 \%$ for Soil 1, and the residual $\mathrm{Cd}$ concentration was below the limit $(0.30 \mathrm{mg} / \mathrm{kg})$ set by the Ministry of Environmental Protection of People's Republic of China (2006). For Soil 3, a liquid-solid ratio of 15 was sufficient to reduce the $\mathrm{Cd}$ concentration to below the $0.30 \mathrm{mg} / \mathrm{kg}$ limit. For Soil 2 , Cd removal efficiency increased rapidly to $80.2 \%$ as the liquidsolid rose from 3 to 20 , and then rose slowly to $88.0 \%$ at a ratio of
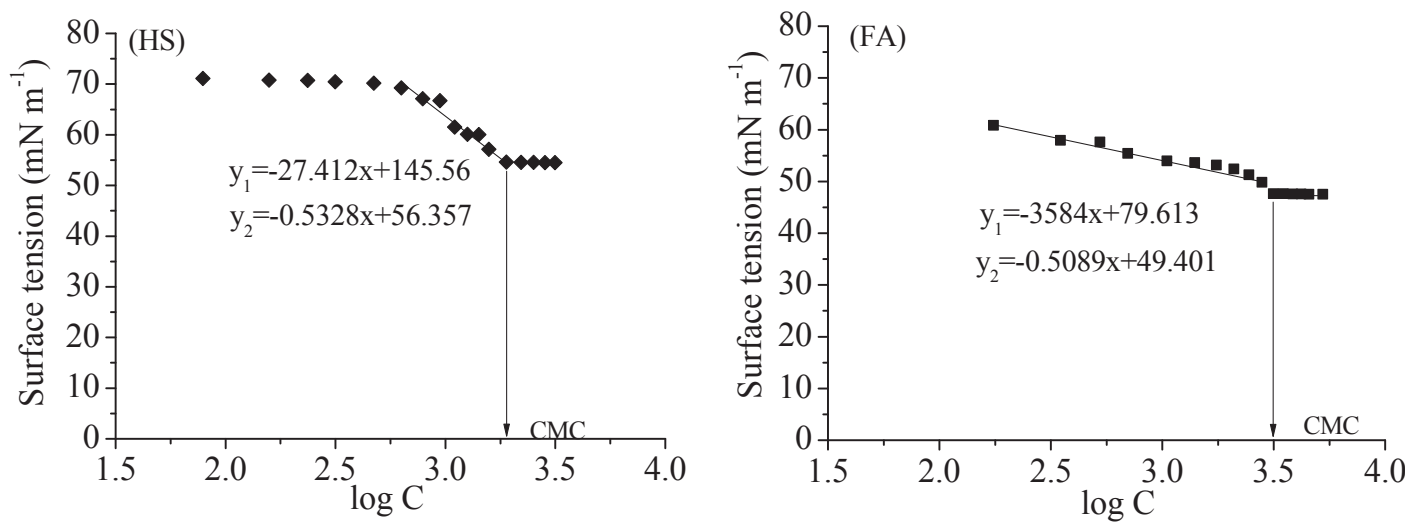

Fig. 1. Determination of the critical micelle concentration (CMC) by plotting surface tension against washing agent concentration (C). 

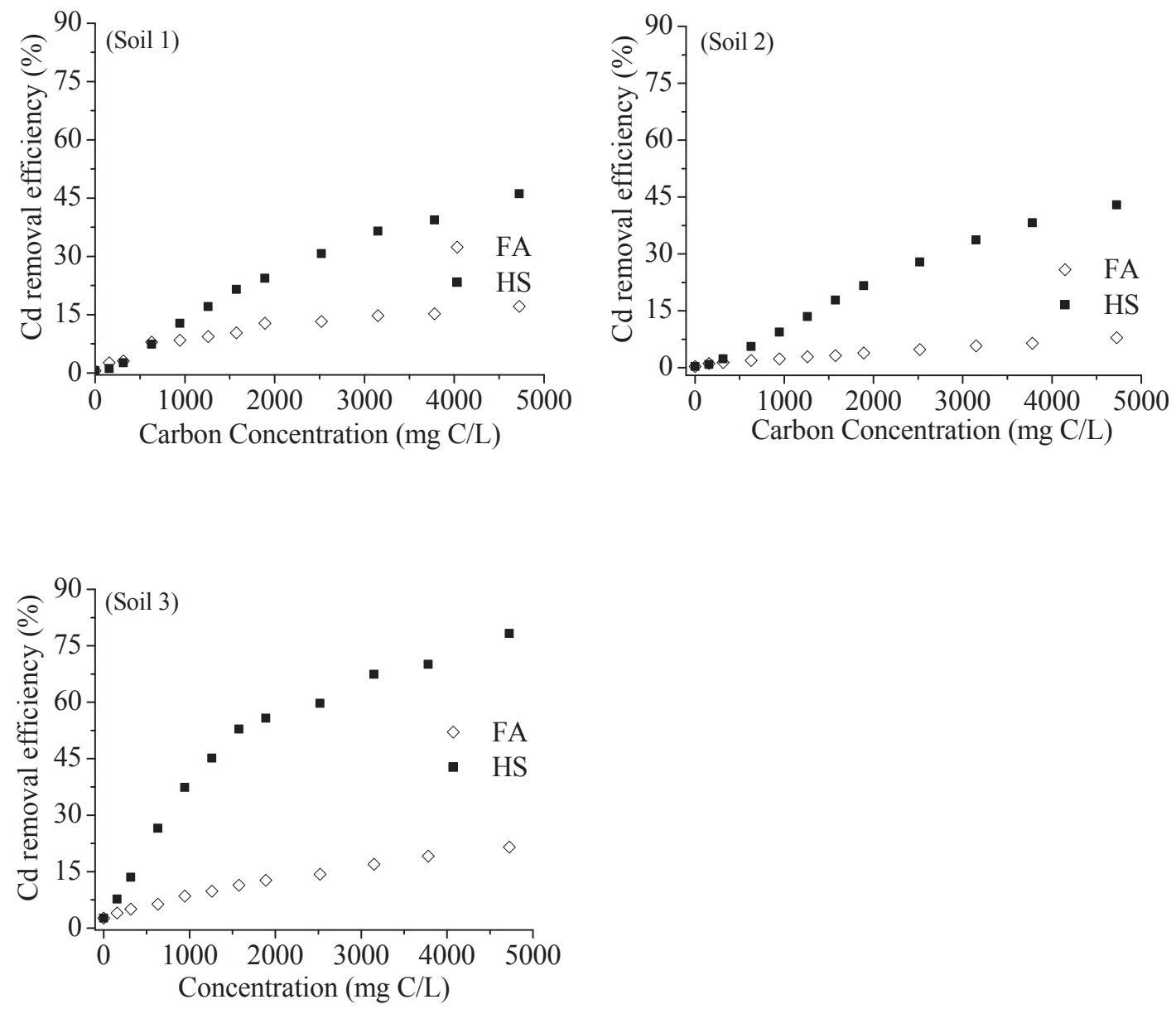

Fig. 2. The effect of washing agent concentrations on $\mathrm{Cd}$ removal efficiency. Experimental conditions: solution $\mathrm{pH}=6.0$, liquid-solid ratio of 5 , washing time $12 \mathrm{~h}$.

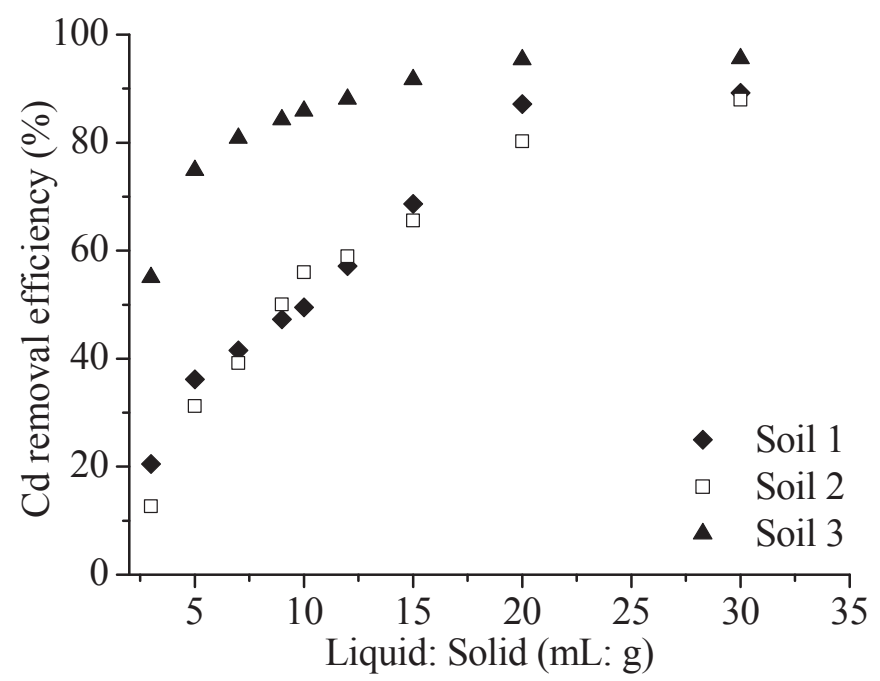

Fig. 3. The effect of liquid: solid ratio on Cd removal efficiency. Experimental conditions: solution $\mathrm{pH}$ : 6.0, washing time: $12 \mathrm{~h}$, humic substance concentration: $3150 \mathrm{mg} \mathrm{C} / \mathrm{L}$.

30. Thus, it is possible to remediate Cd-contaminated soils to meet state requirement by a single washing with humic substances.

Although Cd removal efficiency increased with liquid-solid ratio, there was a trade-off between efficiency and treatment cost.

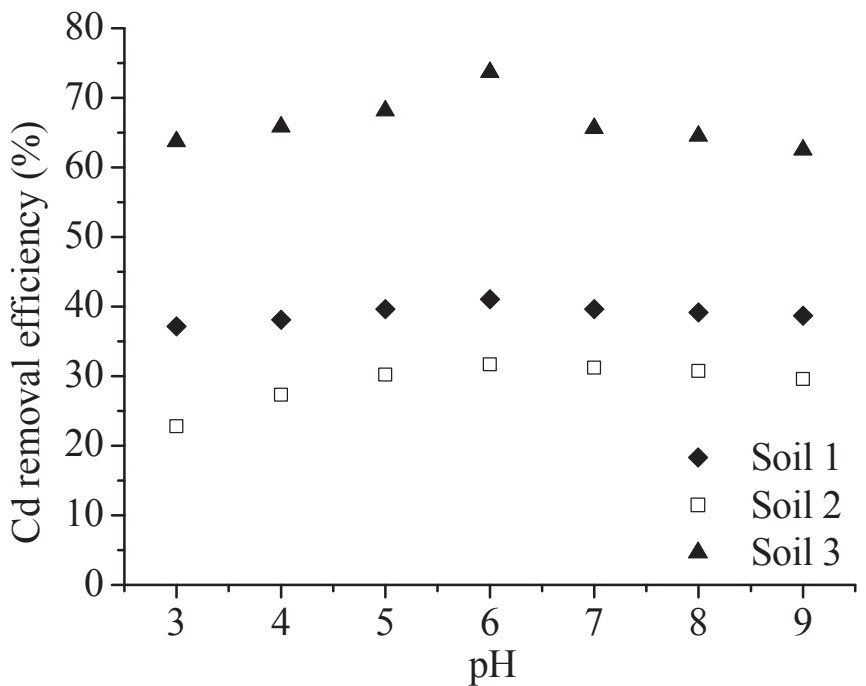

Fig. 4. The effect of solution $\mathrm{pH}$ on $\mathrm{Cd}$ removal efficiency. Experimental conditions: washing time: $12 \mathrm{~h}$, liquid-solid ratio: 5 , humic substance concentration: $3150 \mathrm{mg} \mathrm{C} / \mathrm{L}$.

The higher the liquid-solid ratio, the more waste water was produced. A liquid-solid ratio of 5 was chosen to make practical operation in field cost-effective, by taking into account of water and energy consumption, machinery availability, and ease of effluent treatment. 


\subsection{Effect of $\mathrm{pH}$ on $\mathrm{Cd}$ removal efficiency}

Fig. 4 shows that Cd removal efficiency was slightly greater at near neutral $\mathrm{pH}$ than at either the acidic or alkaline side of neutrality. This observation was in line with the effect of $\mathrm{pH}$ on the mobility of Cd and other heavy metals in soil (Sun et al., 2013, 2016; Cui et al., 2016). At pH 3, Cd removal efficiency was low, possibly because of reduced solubility of humic substances, and their partial precipitation onto soil (clay) particles. At low $\mathrm{pH}$, the carboxylic groups of humic substances would also be less dissociated, while the humic substances molecules become more compact (Lamar et al., 2014; Kulikowska et al., 2015a). As a result, electrostatic interaction between humic substances and soil particles would increase as does humic substance precipitation/adsorption onto soil particles as Wang and Mulligan (2009) had observed for arsenic. Adsorption of humic substances onto soils is a common phenomenon (Simmler et al., 2013; Kulikowska et al., 2015a). At $\mathrm{pH}>7$, Cd removal efficiency decreased as Cd tends to form hydroxides and precipitate, making it more resistant to washing with humic substances. We have therefore chosen $\mathrm{pH} 6$ as an acceptable operational condition.

\subsection{Kinetics of Cd removal by humic substances}

Fig. 5 shows that the amount of Cd removed from soils quickly increased with washing time before a plateau was reached at about $2 \mathrm{~h}$. Thus, $2 \mathrm{~h}$ was chosen as a convenient soil washing time.

Data from the kinetic experiments were fitted into a pseudofirst- and pseudo-second-order model to describe the process of Cd desorption from soil and $\mathrm{Cd}$ adsorption (complexation) to humic substances.

Pseudo-first-order equation:

$\mathrm{q}_{\mathrm{t}}=\mathrm{q}_{1}\left(1-\mathrm{e}^{\left(-\mathrm{k}_{1} \mathrm{t}\right)}\right)$

Pseudo-second-order equation:

$\mathrm{q}_{\mathrm{t}}=\frac{\mathrm{q}_{2}^{2} \mathrm{k}_{2} \mathrm{t}}{1+\mathrm{q}_{2} \mathrm{k}_{2} \mathrm{t}}$

where $\mathrm{q}_{1}$ and $\mathrm{q}_{2}$ are the amount of $\mathrm{Cd}$ adsorbed $(\mathrm{mg} / \mathrm{g})$ at equilibrium, $\mathrm{q}_{\mathrm{t}}$ is the amount of $\mathrm{Cd}$ adsorbed at time $\mathrm{t}(\mathrm{mg} / \mathrm{g}), \mathrm{k}_{1}(1 / \mathrm{h})$ and $\mathrm{k}_{2}(\mathrm{~g} /(\mathrm{mg} \bullet \mathrm{h}))$ are the respective equilibrium rate constants.

In general, the pseudo-first-order model describes the initial kinetics process, whereas the pseudo-second-order model applies to the whole process of adsorption/desorption. The $\mathrm{R}^{2}$ values in Table 2 indicate that $\mathrm{Cd}$ adsorption (complexation) to humic

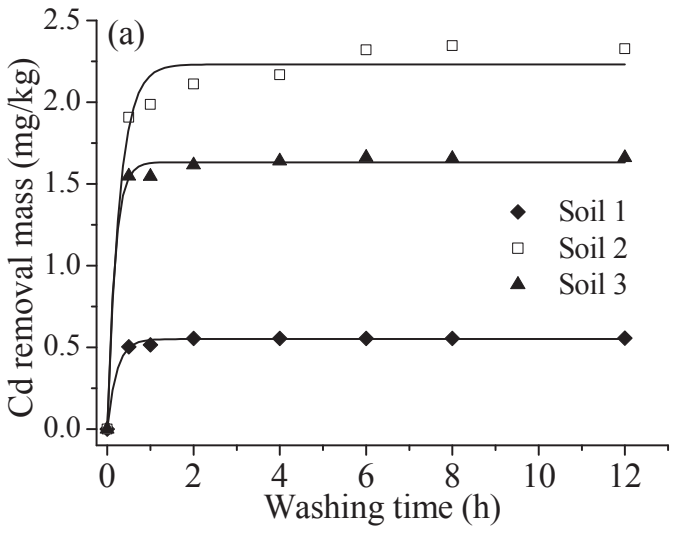

substances (or Cd desorption from soil) was better described by the pseudo-second-order model, indicative of a chemisorption process (Ho and McKay, 1999).

\subsection{Effluent treatment}

As shown in Fig. 6, the wastewater from soil washing can be effectively treated with $\mathrm{Ca}(\mathrm{OH})_{2}$ to reduce $\mathrm{Cd}$ concentration to below the waste water discharge limit in China $(0.1 \mathrm{mg} / \mathrm{L})$. As the

Table 2

Parameters of kinetics of $\mathrm{Cd}$ migration from soils to washing agent humic substances.

\begin{tabular}{llllllll}
\hline Soil & \multicolumn{2}{l}{ pseudo-first-order } & & \multicolumn{3}{l}{ pseudo-second-order } \\
\cline { 2 - 3 } & $\mathrm{q}_{1}(\mathrm{mg} / \mathrm{g})$ & $\mathrm{k}_{1}(\mathrm{~L} / \mathrm{h})$ & $\mathrm{R}_{1}^{2}$ & & $\mathrm{q}_{2}(\mathrm{mg} / \mathrm{g})$ & $\mathrm{k}_{2}(\mathrm{~g} / \mathrm{mg} \mathrm{h})$ & $\mathrm{R}_{2}^{2}$ \\
\hline Soil 1 & 0.55 & 4.6510 & $0.995^{* *}$ & 0.56 & 28.4760 & $0.999^{* *}$ \\
Soil 2 & 2.23 & 3.5035 & $0.977^{* *}$ & 2.32 & 3.3509 & $0.993^{* *}$ \\
Soil 3 & 1.63 & 5.7007 & $0.995^{* *}$ & & 1.66 & 13.5297 & $0.999^{* *}$ \\
\hline
\end{tabular}

${ }^{* *}$ Significant at $\mathrm{P}=0.01$ level.

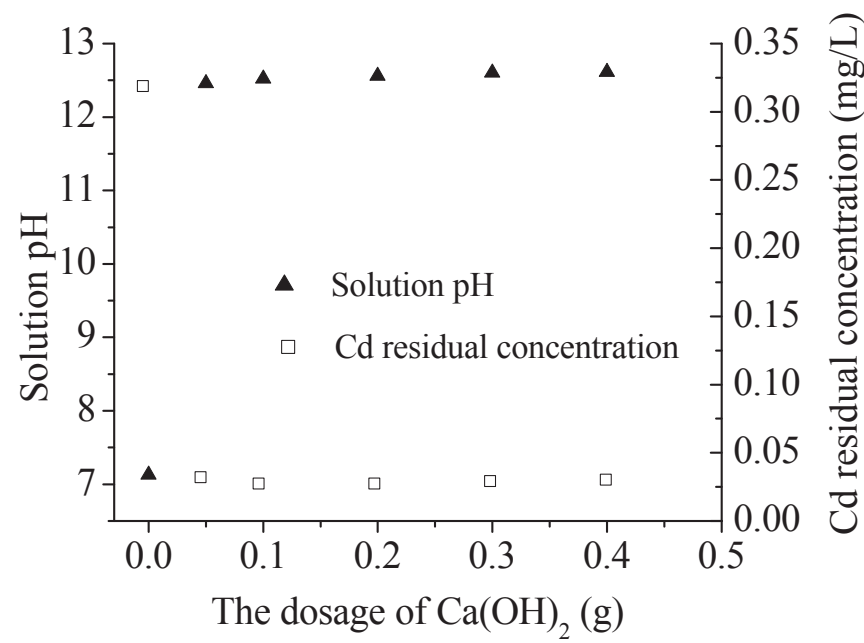

Fig. 6. The relationship between $\mathrm{Ca}(\mathrm{OH})_{2}$ dosage and $\mathrm{Cd}$ residual concentration and solution $\mathrm{pH}$.

$\mathrm{Ca}(\mathrm{OH})_{2}$ dosage increased, effluent pH sharply increased from 7.13 to a plateau value of about 12.5. At the same time, there was a steep fall in Cd concentration from 0.32 to about $0.03 \mathrm{mg} / \mathrm{L}$.

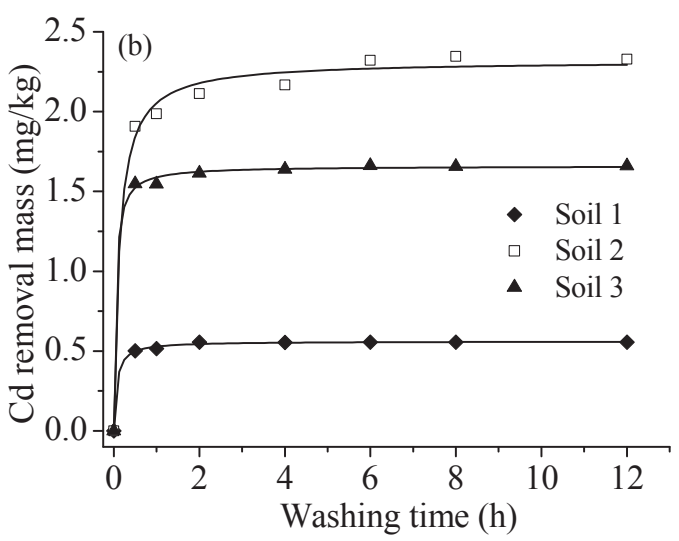

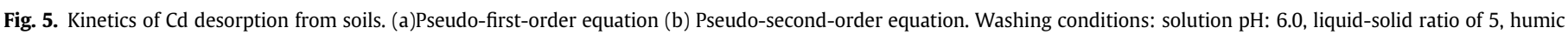
substance concentration: $3150 \mathrm{mg} \mathrm{C/L}$. 
Although $\mathrm{Ca}(\mathrm{OH})_{2}$ is only sparingly soluble in water (solubility product $\mathrm{K}_{\mathrm{sp}}$ of $5.02 \times 10^{-6}$ ), the soluble component is fully ionized: $\mathrm{Ca}(\mathrm{OH})_{2} \rightleftharpoons \mathrm{Ca}^{2+}+2 \mathrm{OH}^{-}$, leading to a high $\mathrm{pH}$ value. Thus, $\mathrm{Ca}(\mathrm{OH})_{2}$ played three roles in effluent treatment. First, its high $\mathrm{pH}$ made humic substances more effective in adsorbing $\mathrm{Cd}^{2+}$ and reduced free $\mathrm{Cd}^{2+}$ in effluent. Second, $\mathrm{Ca}^{2+}$ effectively flocculated almost all humic substances and their adsorbed Cd by forming a Cd-HS-Ca complex. Third, hydroxyl ions from $\mathrm{Ca}(\mathrm{OH})_{2}$ can combine with $\mathrm{Cd}$ to form a $\mathrm{Cd}(\mathrm{OH})_{2}$ precipitate (Baltpurvins et al., 1997). The treatment of waste water effluent with inexpensive $\mathrm{Ca}(\mathrm{OH})_{2}$ is an integral part of the humic substances-based washing technology for soil remediation.

\subsection{Potential application of humic substances in soil remediation}

Yuan (2008) and Makino et al. (2006) have proposed the following guidelines for assessing the suitability of washing agents for soil remediation: (1), these agents should be simple, effective and reliable allowing the contaminants in waste water to be recovered; (2), washing agents must be inexpensive; and (3), they must not be toxic to microbes, leach to groundwater, detrimental to soil structure and fertility, and harmful to plant growth.

Leonardite-derived humic substances apparently meet all of the above requirements (Senesi et al., 1991; Halim et al., 2003; Yuan and Theng, 2011). The humic substances in question contain only trace amount of heavy metals ( $\mathrm{Cd} 0.16, \mathrm{~Pb} 9.59, \mathrm{Cu} 12.49, \mathrm{Cr} 8.73$, As $6.41 \mathrm{Ni} 13.93, \mathrm{Zn} 37.56 \mathrm{mg} / \mathrm{kg}$ ), far below the allowable metal concentration limit for farmland (The Ministry of Environmental Protection of People's Republic of China, 2006), Based on the trade-off between $\mathrm{Cd}$ removal efficiency and operational cost (e.g., time, water availability, and humic substances consumption), proper washing conditions can be determined to suit local soil properties, contamination levels, and remediation requirements. For the three contaminated soils used in this study, a combination of pH 6.0, a washing time of $6 \mathrm{~h}$, liquid-solid ratio of 5, and a humic substances dosage of $3150 \mathrm{mg} \mathrm{C} / \mathrm{L}$ could remove removed $42-75 \%$ of $\mathrm{Cd}$ in a single washing. Further, the $\mathrm{Cd}$ in the wastewater could readily be removed by adding a small dose of cheap $\mathrm{Ca}(\mathrm{OH})_{2}$ to meet effluent discharge requirements. Here we suggest field verifications of the washing method in two occasions. The first is to remediate $\mathrm{Cd}$-contaminated paddy field where water is abundant and mixing soil and water is a normal practice in conjunction with fertilization and the transplantation of seedlings. Humic substances can be added to soil during the soil-water mixing operation. Removal of $\mathrm{Cd}$ from water can be done at drainage exit. The second is to remediate Cd-contaminated urban land for residential development, where the cost of remediation can be well justified, and the washing and effluent treatment can be done on site before the development.

\section{Conclusions}

Leonardite-derived humic substances have a low CMC and a great capacity to adsorb $\mathrm{Cd}$. When used as a washing agent for $\mathrm{Cd}-$ contaminated soils, washing conditions may be tailored to suit soil properties and meet local remediation requirements. Using a humic substance concentration of $3150 \mathrm{mg} \mathrm{C} / \mathrm{L}$, a pH of 6.0, a washing time of $2 \mathrm{~h}$, and a liquid-solid ratio of 5 , a single washing could reduce the $\mathrm{Cd}$ concentration of three Cd-contaminated soils by 41.6 , 36.8 and $74.9 \%$. Further, the Cd concentration in the effluent (waste water) can be easily lowered to meet discharge requirements by treatment with a small dose of $\mathrm{Ca}(\mathrm{OH})_{2}$. Being superior to many washing agents in terms of washing effectiveness, safety, benefits to soil, and low cost, leonardite-derived humic substances have the potential to become the washing agent of choice for the remediation of soils contaminated with Cd and other heavy metals. Paddy field with plenty of water or urban land with a high value could be chosen for a trial in the future.

\section{Acknowledgments}

Valuable discussion with and editorial help from Dr BKG Theng of Landcare Research, New Zealand, was greatly appreciated. This work was supported by Chinese National Key Research and Development Program (2016YFD0200303), the National Natural Science Foundation of China (21577131), the Special Funding for the Introduced Innovative R\&D Team of Dongguan Municipal Government (2014607101003), and Key Research and Development Program of Shandong Province (2016CYJS05A01-1).

\section{References}

Baltpurvins, K.A., Burns, R.C., Lawrance, G.A., Stuart, A.D., 1997. Effect of electrolyte composition on zinc hydroxide precipitation by lime. Water Res. 31, 973-980.

Bolan, N., Kunhikrishnan, A., Thangarajan, R., Kumpiene, J., Park, J., Makino, T., Kirkham, M.B., Scheckel, K., 2014. Remediation of heavy metal(loid)s contaminated soils-To mobilize or to immobilize? J. Hazard. Mater 266, 141-166.

Bucheli-Witschel, M., Egli, T., 2001. Environmental fate and microbial degradation of aminopolycarboxylic acids. FEMS Microbiol. Rev. 25, 69-106.

Conte, P., Agretto, A., Spaccini, R., Piccolo, A., 2005. Soil remediation: humic acids as natural surfactants in the washings of highly contaminated soils. Environ. Pollut. 135, 515-522.

Cui, H., Fan, Y., Xu, L., Zhou, J., Zhou, D., Mao, J., Fang, G., Cang, L., Zhu, Z., 2016 Sustainability of in situ remediation of $\mathrm{Cu}$ - and $\mathrm{Cd}$-contaminated soils with one-time application of amendments in Guixi, China. J. Soil Sediment. 16 $1498-1508$.

Dermont, G., Bergeron, M., Mercier, G., Richer-Laflèche, M., 2008. Soil washing for metal removal: a review of physical/chemical technologies and field applications. J. Hazard. Mater 152, 1-31.

Guo, X.F. Wei, Z.B., Wu, OT., Li, C.P., Oian, T.W., Zheng, W., 2016. Effect of soil washing with only chelators or combining with ferric chloride on soil heavy metal removal and phytoavailability: field experiments. Chemosphere 147 412-419.

Halim, M., Conte, P., Piccolo, A., 2003. Potential availability of heavy metals to phytoextraction from contaminated soils induced by exogenous humic substances. Chemosphere 52, 265-276.

Heil, D.M., Samani, Z., Hanson, A.T., Rudd, B., 1999. Remediation of lead contaminated soil by EDTA. I. Batch and column studies. Water Air Soil Pollut. 113, 77-95.

Ho, Y.S., McKay, G., 1999. Pseudo-second order model for sorption processes. Process Biochem. 34, 451-465.

International Humic Substances Society, 2016. Acidic functional groups of IHSS samples. http://www.humicsubstances.org/acidity.html (accessed in Feburary, 2017).

Kulikowska, D., Gusiatin, Z.M., Bułkowska, K., Kierklo, K., 2015a. Humic substances from sewage sludge compost as washing agent effectively remove $\mathrm{Cu}$ and $\mathrm{Cd}$ from soil. Chemosphere 136, 42-49.

Kulikowska, D., Gusiatin, Z.M., Bułkowska, K., Klik, B., 2015b. Feasibility of using humic substances from compost to remove heavy metals $(\mathrm{Cd}, \mathrm{Cu}, \mathrm{Ni}, \mathrm{Pb}, \mathrm{Zn}$ ) from contaminated soil aged for different periods of time. J. Hazard. Mater 300 $882-891$.

Lamar, R.T., Olk, D.C., Mayhew, L., Bloom, P.R., 2014. A new standardized method for quantification of humic and fulvic acids in humic ores and commercial products. J. AOAC Int. 97, 721-730.

Lehmann, J., Kleber, M., 2015. The contentious nature of soil organic matter. Nature 528 (7580), 60-68.

Lu, K.P., Yang, X., Gielen, G., Bolan, N., Ok, Y.S., Niazi, N.K., Xu, S., Yuan, G.D., Chen, X. Zhang, X.K., Liu, D., Song, Z.L., Liu, X.Y., Wang, H.L., 2017. Effect of bamboo and rice straw biochars on the mobility and redistribution of heavy metals $(\mathrm{Cd}, \mathrm{Cu}$, $\mathrm{Pb}$ and $\mathrm{Zn}$ ) in contaminated soil. J. Environ. Manage 186, 285-292.

Makino, T., Kamiya, T., Takano, H., Itou, T., Sekiya, N., Sasaki, K., Maejima, Y. Sugahara, K., 2007. Remediation of cadmium-contaminated paddy soils by washing with calcium chloride: verification of on-site washing. Environ. Pollut 147, 112-119.

Makino, T., Maejima, Y., Akahane, I., Kamiya, T., Takano, H., Fujitomi, S., Ibaraki, T. Kunhikrishnan, A., Bolan, N., 2016. A practical soil washing method for use in a Cd-contaminated paddy field, with simple on-site wastewater treatment. Geoderma 270, 3-9.

Makino, T., Sugahara, K., Sakurai, Y., Takano, H., Kamiya, T., Sasaki, K., Itou, T., Sekiya, N., 2006. Remediation of cadmium contamination in paddy soils by washing with chemicals: selection of washing chemicals. Environ. Pollut. 144 $2-10$.

Makino, T., Takano, H., Kamiya, T., Itou, T., Sekiya, N., Inahara, M., Sakurai, Y., 2008 Restoration of cadmium-contaminated paddy soils by washing with ferric chloride: Cd extraction mechanism and bench-scale verification. Chemosphere 
70, 1035-1043.

Mao, X., Jiang, R., Xiao, W., Yu, J., 2015. Use of surfactants for the remediation of contaminated soils: a review. J. Hazard. Mater 285, 419-435.

Meng, F.D., Yuan, G.D., Wei, J., Bi, D.X., Wang, H.L., Liu, X.Y., 2016. Humic acid from leonardite for Cd adsorption and potential applications. J. Zhejiang Univ. (Agric Life Sci.) 42, 460-468 (in Chinese with English abstract).

Mulligan, C.N., Yong, R.N., Gibbs, B.F., 2001. Surfactant-enhanced remediation of contaminated soil: a review. Eng. Geol. 60, 371-380.

Rousk, J., Brookes, P.C., Bååth, E., 2009. Contrasting soil pH effects on fungal and bacterial growth suggest functional redundancy in carbon mineralization. Appl. Environ. Microbiol. 75, 1589-1596.

Senesi, N., Miano, T.M., Provenzano, M.R., Brunetti, G., 1991. Characterization, differentiation, and classification of humic substances by fluorescence spectroscopy. Soil Sci. 152, 259-271.

Simmler, M., Ciadamidaro, L., Schulin, R., Madejón, P., Reiser, R., Clucas, L., Weber, P., Robinson, B., 2013. Lignite reduces the solubility and plant uptake of cadmium in pasturelands. Environ. Sci. Technol. 47, 4497-4504.

Soleimani, M., Hajabbasi, M.A., Afyuni, M., Isfahan, S.A., Jensen, J.K., Holm, P.E., Borggaard, O.K., 2010. Comparison of natural humic substances and synthetic ethylenediaminetetraacetic acid and nitrilotriacetic acid as washing agents of a heavy metal-polluted soil. J. Environ. Qual. 39, 855-862.

Sun, Y., Sun, G., Xu, Y., Wang, L., Liang, X., Lin, D., 2013. Assessment of sepiolite for immobilization of cadmium-contaminated soils. Geoderma 193, 149-155.

Sun, Y., Xu, Y., Wang, L., Liang, X., Li, Y., 2016. Reliability and stability of immobilization remediation of $\mathrm{Cd}$ polluted soils using sepiolite under pot and field trials. Environ. Pollut. 208, 739-746.

Tan, K.H., 2014. Humic Matter in Soil and the Environment: Principles and Controversies, second ed. CRC Press, Boca Raton, FL.

Tandy, S., Bossart, K., Mueller, R., Ritschel, J., Hauser, L., Schulin, R., Nowack, B., 2004 Extraction of heavy metals from soils using biodegradable chelating agents. Environ. Sci. Technol. 38, 937-944.
The Ministry of Environmental Protection of People's Republic of China, 2006. Environmental Quality Evaluation Standards for Farmland of Edible Agricultural Products. China Environmental Science Press, pp. 1-7 (in Chinese).

The Ministry of Environmental Protection and the Ministry of Land and Resources of the People's Republic of China, 2014. Bulletin on National Survey of Soil Contamination (2014). China Environmental Protection Industry, pp. 10-11 (in Chinese).

Theng, B.K.G., 2012. Formation and Properties of Clay-Polymer Complexes, second ed. Elsevier, Amsterdam.

Theng, B.K.G., Yuan, G.D., 2008. Nanoparticles in the soil environment. Elements 4 , 395-399.

Wang, S., Mulligan, C.N., 2009. Effect of natural organic matter on arsenic mobilization from mine tailings. J. Hazard. Mater 168, 721-726.

Wu, W., Li, J., Lan, T., Müller, K., Niazi, N.K., Chen, X., Xu, S., Zheng, L., Chu, Y., Li, J., Yuan, G., Wang, H., 2017. Unraveling sorption of lead in aqueous solutions by chemically modified biochar derived from coconut fiber: a microscopic and spectroscopic investigation. Sci. Total Environ. 576, 766-774.

Yang, X., Liu, J., McGrouther, K., Huang, H., Lu, K., Guo, X., He, L., Lin, X., Che, L., Ye, Z., Wang, H., 2016. Effect of biochar on the extractability of heavy metals (Cd, Cu, $\mathrm{Pb}$ and $\mathrm{Zn}$ ) and enzyme activity in soil. Environ. Sci. Pollut. Res. 23, 974-984.

Yuan, G.D., 2008. Nanomaterials to the rescue. Nanotoday 3, 61.

Yuan, G.D., Theng, B.K.G., 2011. Clay-organic interactions in soil environments. In: Huang, P.M., Sumner, M., Li, Y.C. (Eds.), Handbook of Soil Science: Resource Management and Environmental Impacts, second ed. CRC Press, Boca Raton, FL. pp. $2-1-2-20$.

Yuan, G.D., Theng, B.K.G., Churchman, G.J., Gates, W.P., 2013. Clays and clay minerals for pollution control. In: Bergaya, F., Lagaly, G. (Eds.), Handbook of Clay Science: Techniques and Applications, second ed. Elsevier, Amsterdam, pp. 587-644.

Zeng, Q.R., Sauvé, S., Allen, H.E., Hendershot, W.H., 2005. Recycling EDTA solutions used to remediate metal-polluted soils. Environ. Pollut. 133, 225-231. 